\title{
Bi-criteria evaluation of the MIKE SHE model for a forested watershed on the South Carolina coastal plain
}

\author{
Z. Dai ${ }^{1}$, C. Li ${ }^{1}$, C. Trettin ${ }^{2}$, G. Sun $^{3}$, D. Amatya ${ }^{2}$, and H. Li ${ }^{2}$ \\ ${ }^{1}$ CSRC, EOS, University of New Hampshire, Durham, NH 03824, USA \\ ${ }^{2}$ Center for Forested Wetlands Research, US Forest Service, 3734 Highway 402, Cordesville, SC 29434, USA \\ ${ }^{3}$ South Global Change Program, US Forest Service, Venture II, Suite 300, Raleigh, NC 27606, USA
}

Received: 28 October 2009 - Published in Hydrol. Earth Syst. Sci. Discuss.: 13 January 2010

Revised: 3 May 2010 - Accepted: 20 May 2010 - Published: 24 June 2010

\begin{abstract}
Hydrological models are important tools for effective management, conservation and restoration of forested wetlands. The objective of this study was to test a distributed hydrological model, MIKE SHE, by using bi-criteria (i.e., two measurable variables, streamflow and water table depth) to describe the hydrological processes in a forested watershed that is characteristic of the lower Atlantic Coastal Plain. Simulations were compared against observations of both streamflow and water table depth measured on a firstorder watershed (WS80) on the Santee Experimental Forest in South Carolina, USA. Model performance was evaluated using coefficient of determination $\left(R^{2}\right)$ and Nash-Sutcliffe's model efficiency $(E)$. The $E$ and root mean squared error (RMSE) were chosen as objective functions for sensitivity analysis of parameters. The model calibration and validation results demonstrated that the streamflow and water table depth were sensitive to most of the model input parameters, especially to surface detention storage, drainage depth, soil hydraulic properties, plant rooting depth, and surface roughness. Furthermore, the bi-criteria approach used for distributed model calibration and validation was shown to be better than the single-criterion in obtaining optimum model input parameters, especially for those parameters that were only sensitive to some specific conditions. Model calibration using the bi-criteria approach should be advantageous for constructing the uncertainty bounds of model inputs to simulate the hydrology for this type of forested watersheds. $R^{2}$ varied from $0.60-0.99$ for daily and monthly streamflow, and from $0.52-0.91$ for daily water table depth. $E$ changed from $0.53-0.96$ for calibration and $0.51-0.98$ for validation of daily and monthly streamflow, while $E$ varied from 0.50
\end{abstract}

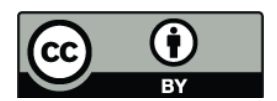

Correspondence to: Z. Dai (zdai@fs.fed.us)
0.90 for calibration and $0.66-0.80$ for validation of daily water table depth. This study showed that MIKE SHE could be a good candidate for simulating streamflow and water table depth in coastal plain watersheds.

\section{Introduction}

Computer models are effective tools for understanding and quantifying watershed hydrology, but may be limited by various constraints of different model types. Most hydrological models are lumped using spatially averaged conditions for the study sites (Singh et al., 1999). However, geological and hydrological conditions in a large catchment or watershed may exhibit considerable spatial and temporal variability such that it can be difficult to accurately describe their hydrology using lumped hydrological models. In contrast, distributed models consider spatial variability in watersheds and are widely used. Nevertheless, the distributed models may also have some disadvantages, such as equifinality due to over-parameterization (Beven, 2006) and uncertainties in model predictions due to variability in the large number of input parameters (Vrugt et al., 2007). Because of the high uncertainties, distributed models may perform poorly even if they are calibrated well using data from another time period (Kirchner, 2006); similar problems can also occur when models are tested against data from different study sites. In general, distributed models are most likely to perform better than lumped models because of their capability to utilize spatial and temporal characteristics of watersheds (Refsgaard, 1997).

Distributed models require appropriate calibration and validation, which has been recognized and emphasized by users and developers of hydrological models (Freer et al., 2003).

Published by Copernicus Publications on behalf of the European Geosciences Union. 


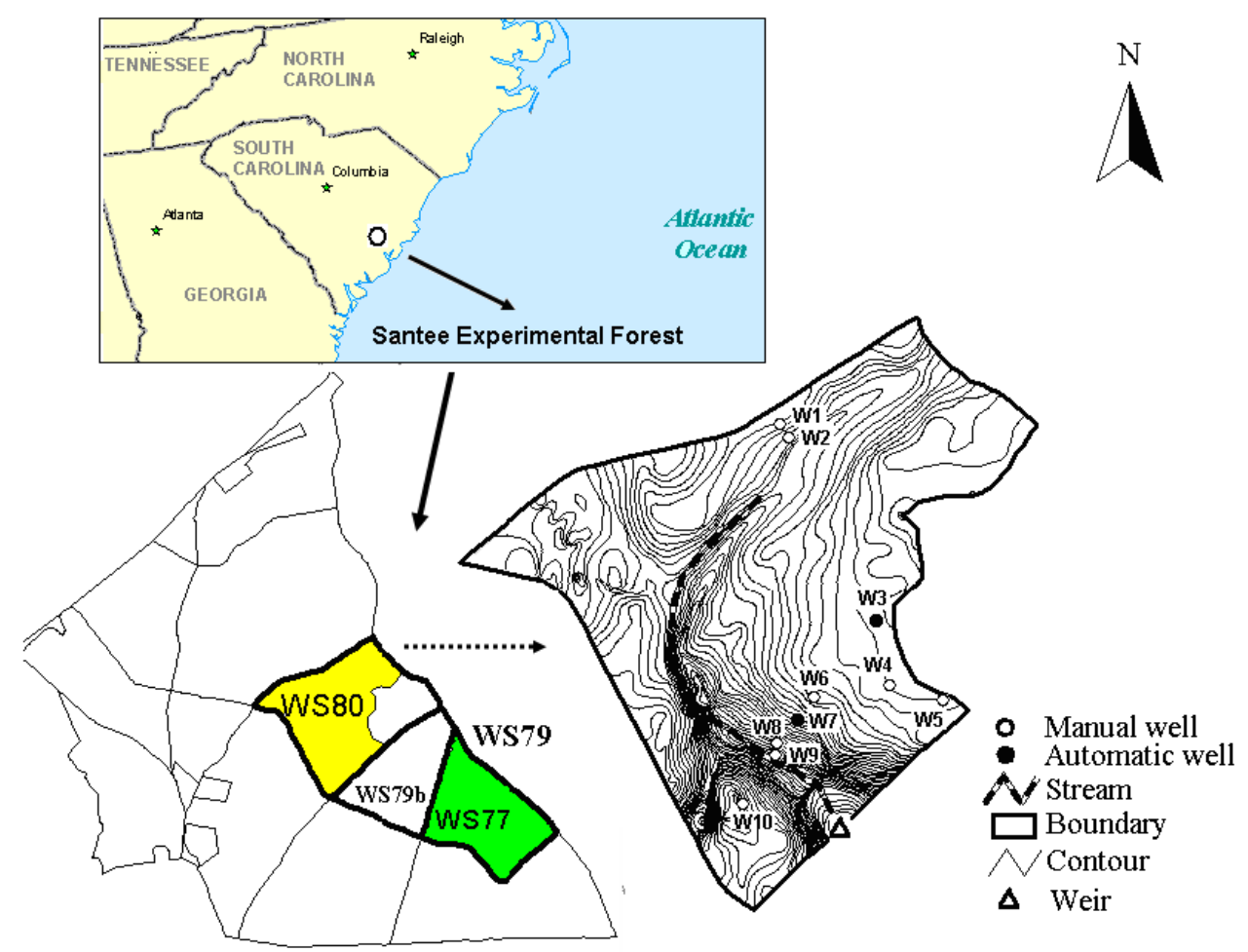

Fig. 1. Location of the study watershed (WS80) on the Santee Experimental Forest, South Carolina, USA. WS80 is 160 ha; the location of the groundwater wells is indicated on the topographic map figure as W1 through W10.

Typically, hydrological model performance is evaluated by comparing the predicted values of discharge with the observed values. However, discharge is usually measured at the outlet of a sub-basin on a watershed due to limited resources for complex measuring equipment, time and personnel. Therefore, there is considerable merit in evaluating hydrological model performance by including more variables (i.e., a multiple criteria approach) (Boyle et al., 2003; Meixner et al., 2003; Shrestha and Rode, 2008). Water table depth is an important measurable hydrological variable to be used for distributed model calibration and validation (Lamb et al., 1998; Blasone et al., 2008; Vázquez et al., 2008) because it affects hydrological processes such as discharge and evapotranspiration. However, it can be influenced by many factors, such as topography, hydro-geology, soil and vegetation. It can vary largely in space and time in watersheds, especially in large river catchments with low-relief landscape. Model evaluation using the bi-criteria approach (i.e., one with two measurable variables, discharge and water table depth) allows for closer examination of the internal consistency of the model (El-Nasr et al., 2001) and for better determination of model biases, especially in watersheds associated with high spatial heterogeneity with respect to geology, soils and vegetation.

Accurately predicting the hydrological conditions governing wetland ecology is necessary to assess the ramifications of land use change and climate change to the functions and services of the wetland ecosystems. Although hydrological models for the wetland systems have been constructed in the past (Sun et al., 1998; Mansell et al., 2000; Martinez et al., 2008), other types of models describing wetland hydrology such as DRAINMOD (Amatya and Skaggs, 2001) and SWAT (Arnold et al., 2001) are also available. Most of those models either are primarily used for simulating field-scale hydrological processes (Amatya et al., 2003; El-Sadek, 2007; Liu et al., 2007) or have not been thoroughly evaluated with spatial distributions of water table (Lu et al., 2009). The MIKE SHE model has been tested in recent years for multiple sites in the USA (Sahoo et al., 2006; Lu et al., 2009) and around the world (Graham and Butts, 2005; Mernild et al., 2008; Vázquez et al., 2008; Staes et al., 2009). These testing results indicate that MIKE SHE is well suited for watersheds containing both uplands and wetlands. However, this model was mostly calibrated and validated using a single variable (either discharge or water table) (Sahoo et al., 2006; Lu et al., 2006; Zhang et al., 2008). The objective of this study was to evaluate the ability of MIKE SHE to simulate the hydrology of a forested watershed containing both uplands and wetlands on the Atlantic Coastal Plain of South Carolina using a bi-criteria (streamflow and water table depth) calibration and validation approach. 


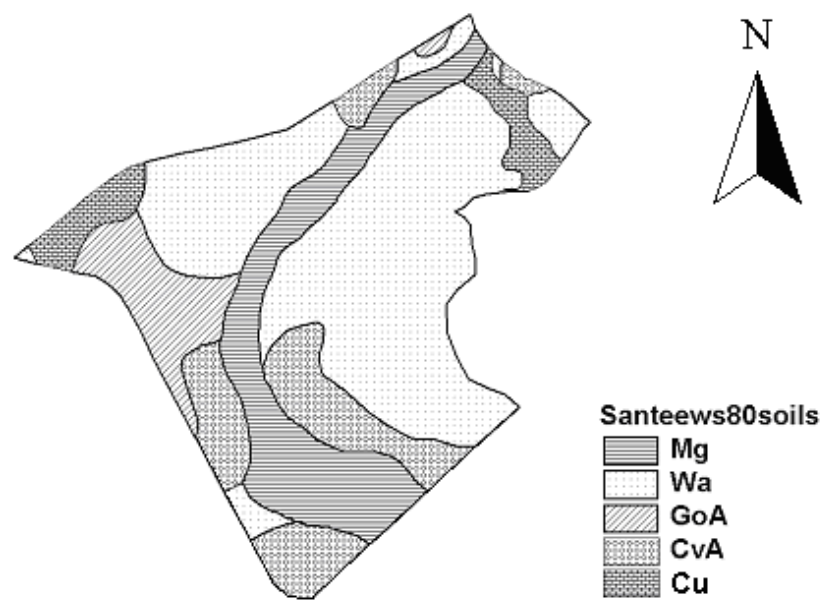

Fig. 2a. Distribution of soil types in WS80. Mg is Meggett, loam; Wa is Wahee, loam; GoA is Goldsboro, sandy loam; CvA is Craven, loam; $\mathrm{Cu}$ is Coxville, fine sandy loam.

\section{Method}

\subsection{Site description}

We chose a first-order watershed (WS80) on the Santee Experimental Forest (SEF) for this study because it contains both uplands and wetlands and is one of the longterm monitored watersheds. The 160 ha watershed is located at $33.15^{\circ} \mathrm{N}, 79.8^{\circ} \mathrm{W}$, and $55 \mathrm{~km}$ northwest of Charleston, South Carolina (Fig. 1). WS80 serves as the control watershed for a paired watershed system (WS77 and WS80) within a second-order watershed (WS79, $500 \mathrm{ha}$ ) draining into the Huger Creek, a tributary of East Branch of the Cooper River. The site has gauging records since 1967. It is characteristic of the subtropical region of the Atlantic Coast with short, warm and humid winters and long and hot summers; the 30-year (1971-2000) average temperature is $18.7^{\circ} \mathrm{C}$, and the mean annual precipitation is $1350 \mathrm{~mm}$ (Amatya et al., 2003). The topography is planar, and the slope is less than $4 \%$. The elevation is between $4-10 \mathrm{~m}$ above mean sea level. WS80 has a shallow water table, and about $23 \%$ of the watershed is classified as wetlands (Sun et al., 2000; Harder et al., 2007).

The soils developed in coastal plain sediments are hydric (Federal Register, 1994, 2002), moderately well drained in the upland and poorly drained in the riparian zone (SCS, 1980; Fig. 2a). The main soil type is loamy, covering about $90 \%$ of the watershed. Clay content is $\leq 30 \%$ in topsoil (within $30 \mathrm{~cm}), 40-60 \%$ in subsoil $(>30 \mathrm{~cm})(\mathrm{SCS}, 1980)$. Soil reaction is acidic; $\mathrm{pH}$ is between 4.5 and 6.5. The available water capacity is between 0.1 and $0.2 \mathrm{~cm} \mathrm{~cm}^{-1}$.

The forest vegetation on WS80 has not been managed in more than five decades (Amatya et al., 2003; Harder et al., 2007). However, the forest was heavily impacted by Hurricane Hugo in 1989 (Hook et al., 1991). This site remained

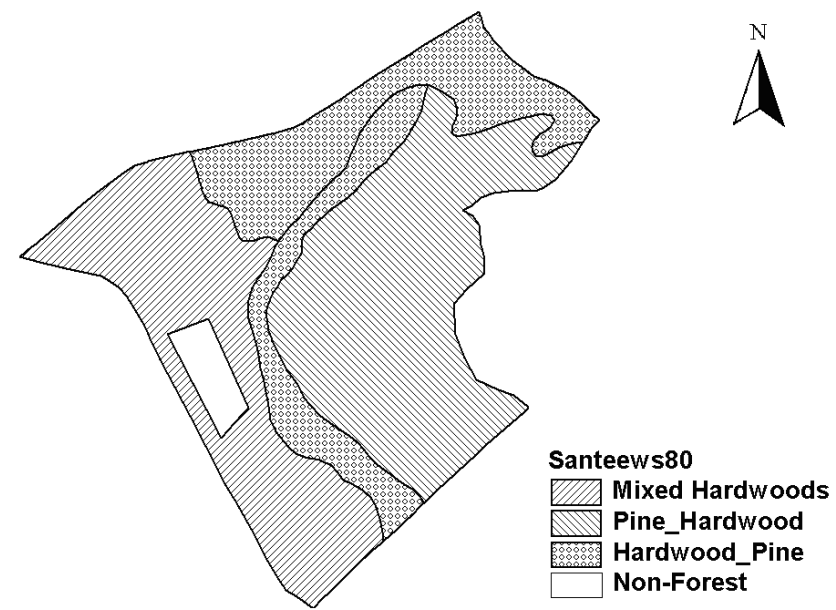

Fig. 2b. Vegetation types in WS80.

unmanaged after the hurricane, without biomass removal or salvage logging. Most of the trees regenerated naturally after the hurricane. The current forest cover (Fig. 2b) consists of bottomland hardwoods in the riparian zone and mixed pinehardwoods elsewhere (Harder et al., 2007). The dominant trees are loblolly (Pinus taeda L.), sweetgum (Liquidambar styraciflua) and a variety of oak species (Queercus spp.) (Hook et al., 1991; Harder et al., 2007).

\subsection{Field measurements and data collection}

Precipitation and air temperature were measured on-site at hourly intervals. Additional meteorological data were collected at 30-min intervals at a weather station at the Santee Experimental Forest Headquarters (SEFH) about $3 \mathrm{~km}$ away from the study site. The measurements included precipitation, solar and net radiation, wind speed, wind direction, temperature, vapor pressure, and relative humidity, which were processed to estimate daily potential evapotranspiration (PET) using the Penman-Monteith method (Xu and Singh, 2005; Harder et al., 2007).

Water table depth was measured at 4-h intervals (20032007) by two automatic recording wells that were installed in an upland area (Global Water's WL-16; the well was $230 \mathrm{~cm}$ deep) and a lowland area (Remote Data Systems' WL-40; the well was $54 \mathrm{~cm}$ deep before March 2004 and $94 \mathrm{~cm}$ afterwards) to record water table elevation. Eight manual wells ( $\geq 2 \mathrm{~m}$ deep) were installed across the watershed with biweekly measurements (2003-2004) (Fig. 1). An automatic Teledyne ISCO-4210 flow meter measured stream gauge heights above a compound V-notch weir at 10-min intervals at the watershed outlet. The streamflow was calculated using a standard rating curve method developed for the weir. The 10-min values were integrated into daily and monthly streamflow in cubic meters per second, and then normalized to millimeters per day to be comparable to daily 
Table 1. Measured vs. simulated streamflow, water table and $\mathrm{ET}^{\mathrm{a}}$.

\begin{tabular}{llllllllllllll}
\hline Year & Rainfall & \multicolumn{4}{c}{ Streamflow $(\mathrm{mm})$} & \multicolumn{4}{c}{ Water table Depth (m) } & \multicolumn{3}{c}{ ET (mm) } \\
& $(\mathrm{mm})$ & $M$ & $S$ & $R^{2}$ & $E$ & $M$ & $S$ & $R^{2}$ & $E$ & PET & AET \\
\hline 2003 & 1671 & 2.01 & 1.90 & 0.62 & 0.53 & 0.58 & 0.52 & 0.91 & 0.90 & 914 & 874 \\
2004 & 962 & 0.28 & 0.37 & 0.60 & 0.56 & 0.81 & 0.78 & 0.65 & 0.65 & 1160 & 774 \\
2005 & 1540 & 0.84 & 0.87 & 0.61 & 0.51 & 0.76 & 0.71 & 0.79 & 0.78 & 1217 & 1037 \\
2006 & 1255 & 0.38 & 0.52 & 0.77 & 0.75 & 1.02 & 1.09 & 0.66 & 0.65 & 1170 & 965 \\
2007 & 923 & 0.16 & 0.21 & 0.79 & 0.73 & 1.06 & 1.16 & 0.73 & 0.56 & 1199 & 822 \\
2008 & 1562 & 0.87 & 0.95 & 0.68 & 0.64 & 0.53 & 0.47 & 0.71 & 0.66 & 1156 & 1064 \\
\hline
\end{tabular}

a: $M$ is measurement; $S$ is simulation; $R^{2}$ is the coefficient of determination; $E$ is Nash-Sutcliffe model efficiency; PET is potential evapotranspiration estimated based on the climate at the meteorological station at Santee Headquarters; AET is the estimated actual evapotranspiration from 10 points where the 10 wells are located. The water table depth is the distance from the ground surface to the water table level below the ground surface.

precipitation. The measured daily mean streamflow and average water table depth are presented in Table 1.

The physical soil properties were obtained from SoildataMart of NRC (http://soildatamart.nrcs.usda.gov). Topography was obtained from a traditional topographic survey of WS80 done in 1982 with $15 \mathrm{~cm}$ contour and in the scale of 1:200. In addition to leaf area index (LAI) calculated from measured leaf biomass, LAI was also measured periodically through the year using a LI-2000 leaf area meter.

\subsection{The MIKE SHE model}

MIKE SHE is a GIS-based distributed model designed for applications in low-relief terrains (Graham and Butts, 2005). It is a spatially and temporally explicit, modularized modeling system. This model simulates the complete terrestrial water cycle by coupling with the flow routing model MIKE 11 (DHI, 2005; Sahoo et al., 2006), including saturated water movement in soils, 2-D water movement of overland flow, 1-D water movement in rivers/streams, unsaturated water movement and evapotranspiration (ET). Saturated water movement in soils is modeled using 3-D Finite Difference or Linear Reservoir. The 2-D water movement of overland flow is simulated using Finite Difference or Subcatchment-based method. The diffusive wave version of Saint Venant equations is used to simulate 1-D water movement in rivers/streams. The unsaturated water movement is simulated using either Richards equation or Gravity Flow or Two-Layer water balance method (DHI, 2005). Detailed descriptions of the model and algorithms can be found in many publications (Abbott et al., 1986a, b; DHI, 2005; Graham and Butts, 2005).

\subsection{Model setup and parameterization}

In this study, we simulated the full hydrological cycle of the watershed, including evapotranspiration, infiltration, unsaturated flow, saturated flow, overland flow and stream flow. The main inputs for the model included spatial data on topography, soils, vegetation, and drainage network; and temporal data on precipitation and potential evapotranspiration (PET) based on Penman-Monteith (Monteith, 1965; Xu and Singh, 2005; Harder et al., 2007). To apply MIKE SHE, this study site (Fig. 1) was divided into $675(50 \mathrm{~m}$ by $50 \mathrm{~m})$ cells.

\subsubsection{Unsaturated flow}

The Two-Layer Water Balance model (Yan and Smith, 1994; DHI, 2005), which is designed for the areas with a shallow groundwater table, was used to simulate the unsaturated flow for this study. The model divides the unsaturated zone into a root-zone where ET can occur, and a below-root-zone where ET does not occur (Yan and Smith, 1994). The model inputs were given in Table 2, including vegetation characteristics (cover, LAI and plant rooting depth) and the physical soil properties (infiltration capacity, and the soil moisture contents at the wilting point, saturation and field capacity). The data for physical soil properties and vegetation characteristics (Fig. 2a, b) were spatially distributed to simulate unsaturated flow in space and time.

\subsubsection{Saturated flow}

The 3-D finite difference method (DHI, 2005) was used to simulate the saturated flow for this study. The inputs needed to simulate saturated flow were soil hydraulic properties, including horizontal and vertical hydraulic conductivities, specific yield, and storage coefficient. Horizontal hydraulic conductivity $\left(K_{\mathrm{x}}\right)$ significantly influences base, peak 
Table 2. Initial values of important parameters of MIKE SHE simulation model ${ }^{\mathrm{a}}$.

\begin{tabular}{ll}
\hline Parameter & Value \\
\hline Plant rooting depth $[\mathrm{mm}]$ & 500 \\
Leaf area index (LAI) $\left[\mathrm{m}^{2} \mathrm{~m}^{-2}\right]$ & $0.2-6.6$ (2.8 on average) \\
Potential evapotranspiration (PET) $\left[\mathrm{mmd}^{-1}\right](\mathrm{P}-\mathrm{M})$ & $0.0-7.5$ \\
Detention storage $[\mathrm{mm}]$ & 40 \\
Manning $M\left[\mathrm{~m}^{1 / 3} \mathrm{~s}^{-1}\right]$ & 40 \\
Initial water depth $[\mathrm{m}]$ & 0 \\
Soil water content at saturated conditions $(\mathrm{WCSC})\left[\mathrm{m}^{3} \mathrm{~m}^{-3}\right]$ & $0.4-0.496$ \\
Soil water content at field capacity $(\mathrm{WCFC})\left[\mathrm{m}^{3} \mathrm{~m}^{-3}\right]$ & $0.3-0.458$ \\
Soil water content at wilting point $\left(\mathrm{WCWP}^{-3}\left[\mathrm{~m}^{3} \mathrm{~m}^{-3}\right]\right.$ & $0.2-0.38$ \\
Infiltration $\left[\cdot 10^{-6} \mathrm{~ms}{ }^{-1}\right]$ & $1-100$ \\
ET surface depth $[\mathrm{m}]$ & 0.2 \\
Horizontal hydraulic conductivity $\left[\cdot 10^{-6} \mathrm{~ms}^{-1}\right]$ & $10-800$ \\
Vertical hydraulic conductivity $\left[\cdot 10^{-6} \mathrm{~ms}^{-1}\right]$ & $1-80$ \\
Drainage depth $[\mathrm{m}]$ & 0.5 \\
Drainage time constant $\left[\mathrm{s}^{-1}\right]$ & $1 \mathrm{e}-07$ \\
$C_{\text {int }}[\mathrm{mm}]$ & 0.10 \\
\hline
\end{tabular}

${ }^{\mathrm{a}}: C_{\mathrm{int}}$ is the coefficient of canopy interception used in MIKE SHE (DHI, 2005); P-M stands for the Penman-Monteith method.

and subsurface flows. Overland flow, subsurface flow (lateral flow) and ground water table level are significantly affected by the values of vertical hydraulic conductivity $\left(K_{\mathrm{y}}\right)$. Both the horizontal and vertical hydraulic conductivities used in this study were spatially distributed based on the distribution of soils (Fig. 2a).

A drainage depth (from the phreatic surface to the level where the flow of drainage water can occur) and a drainage time constant are required for simulating the flow of drainage water using an empirical formula in MIKE SHE. Both these parameters are important for simulating subsurface flow. The drainage time constant affects streamflow, with small values delaying subsurface flow to reach the stream. In contrast, the drainage depth can significantly influence both the streamflow and water table depth. When the water table rises above the elevation of the drainage depth, drainage starts and varies linearly with change in the difference between water table level and drainage depth. Therefore, lower drainage depths (below the ground surface) yield deeper water table level. The drainage depth was initialized to $50 \mathrm{~cm}$ due to shallow water table in this study area.

\subsubsection{Overland flow and stream flow}

Overland flow was simulated using diffusive wave approximation. The inputs include initial water depth on the surface, surface detention storage, and Manning number $(M)$. The measured surface water depth was used to initialize the water depth above the ground surface for the model to run. Surface detention storage largely affects routing water toward the stream and water table dynamics. Large values of surface detention storage reduce the overland flow reaching the stream, but increase ponding water that may lead to a subsequent increase in water table level. Manning $M$ significantly influences routing overland flow toward the stream and stream flow toward the outlet of the stream with higher values leading to faster water movement.

\subsubsection{Evapotranspiration (ET)}

In this study, daily ET was simulated using the Two-Layer Water Balance model (Yan and Smith, 1994; DHI, 2005). Actual daily evapotranspiration (AET) was estimated as:

$$
\mathrm{AET}=E_{c}+E_{p}+E_{u}+E_{s}
$$


Table 3. Root mean squared error (RMSE) and Nash and Sutcliffe's model efficiency $(E)$ from calibrations for water table and streamflow ${ }^{\text {a }}$.

\begin{tabular}{lccccc}
\hline Parameter & Value & \multicolumn{2}{c}{ Water table } & \multicolumn{2}{c}{ Streamflow } \\
& (min-max) & RMSE & $E$ & RMSE & $E$ \\
\hline$C_{\text {int }[\mathrm{mm}]}$ & $0.05-0.80$ & $0.168-0.171$ & $0.54-0.55$ & $3.48-3.57$ & $0.55-0.57$ \\
Drainage depth [m] & $0.0-1.0$ & $0.19-0.61$ & $-4.93-0.45$ & $3.20-3.76$ & $0.50-0.64$ \\
Detention storage [mm] & $5-100$ & $0.18-0.32$ & $-0.59-0.49$ & $3.44-3.98$ & $0.43-0.58$ \\
Manning $M\left[\mathrm{~m}^{1 / 3} \mathrm{~s}^{-1}\right]$ & $10-70$ & $0.182-0.183$ & $0.46-0.47$ & $3.21-3.65$ & $0.53-0.64$ \\
HHC $\left[\cdot 10^{-6} \mathrm{~ms}^{-1}\right]$ & $1-5000$ & $0.18-0.94$ & $-13.2-0.46$ & $2.53-3.61$ & $0.54-0.77$ \\
VHC $\left[\cdot 10^{-6} \mathrm{~ms}^{-1}\right]$ & $0.5-100$ & $0.185-0.186$ & 0.45 & $3.35-3.40$ & $0.58-0.60$ \\
Plant rooting depth $[\mathrm{mm}]$ & $300-900$ & $0.17-0.24$ & $0.05-0.54$ & $3.48-3.50$ & 0.57 \\
Infiltration rate $\left[\cdot 10^{-6} \mathrm{~ms}{ }^{-1}\right]$ & $1-1000$ & $0.182-0.183$ & 0.47 & $3.48-3.54$ & $0.56-0.57$ \\
WCSC $\left[\mathrm{m}^{3} \mathrm{~m}^{-3}\right]^{\mathrm{b}}$ & $0.40-0.66$ & $0.16-0.20$ & $0.38-0.59$ & $3.48-3.53$ & $0.56-0.57$ \\
WCFC $\left[\mathrm{m}^{3} \mathrm{~m}^{-3}\right]^{\mathrm{b}}$ & $0.30-0.50$ & $0.15-0.21$ & $0.33-0.63$ & $3.45-3.49$ & $0.57-0.58$ \\
WCWP $\left[\mathrm{m}^{3} \mathrm{~m}^{-3}\right]^{\mathrm{b}}$ & $0.25-0.45$ & $0.19-0.20$ & $0.32-0.45$ & $3.50-3.53$ & $0.56-0.57$ \\
\hline
\end{tabular}

a: HHC is horizontal hydraulic conductivity; VHC is vertical hydraulic conductivity; WCSC is soil water content at saturated conditions; WCFC is soil water content at field capacity; WCWP is soil water content at wilting point; ${ }^{\mathrm{b}}$ : The value is dependent on soil type; $C_{\text {int }}$ is coefficient of canopy interception.

Where $E_{c}$ is the daily evaporation from canopy; $E_{p}$ is the daily evaporation from soil or ponded water; $E_{u}$ is the daily ET from unsaturated zone extracted by plant; $E_{s}$ is the daily ET from saturated zone extracted by plants. The key parameters used to calculate AET include LAI, plant rooting depth, coefficient of canopy interception $\left(C_{\text {int }}\right)$, ET surface depth, and surface detention storage.

\subsubsection{Simulation time steps}

MIKE SHE has the flexibility of using variable simulation time steps for different hydrological modeling components and flow characteristics (DHI, 2005; Zhang et al., 2008). In this study, maximum allowed time steps were set to $2 \mathrm{~h}$ for unsaturated flow, overland flow and ET, $4 \mathrm{~h}$ for saturated flow, and $10 \mathrm{~min}$ for channel flow. The time steps for outputs were $4 \mathrm{~h}$ for streamflow and $24 \mathrm{~h}$ for water table depth.

\subsubsection{Boundaries of surface flow and subsurface flow}

In this study, it was assumed that the boundary of subsurface ground water area was the same as that of the surface water flow of the watershed because the watershed is bordered by roads (except for its northeast section) that are well compacted to minimize lateral flows across the borders. Ground water and surface flow across the northeast border was assumed minimal as compared to the overall flows based on the water balance in this watershed analyzed by Harder et al. (2007). Typically, the deep seepage was considered as only a small fraction of total precipitation on Atlantic Coastal areas (Heath, 1975; Riekerk et al., 1979; Harder et al., 2007); thus, it was assumed negligible.

\section{Model calibration and validation}

Unlike most previous studies, this study used both streamflow and water table depth for model calibration and validation. Model calibration was conducted through sensitivity analysis using data observed in 2003, while model validation was performed with the data from 2004 to 2008 . The observed data in this six-year study period (2003-2008) consisted of wet, dry and normal rainfall years. The wet year was 2003 with $1671 \mathrm{~mm}$ of precipitation, about $320 \mathrm{~mm}$ higher than the 30-year average (1350 mm during 1971-2000) (Amatya et al., 2003). The dry years were 2004 and 2007 with precipitation of 962 and $923 \mathrm{~mm}$, about $400 \mathrm{~mm}$ lower than the 30-year average. The years of 2005, 2006, and 2008 were relatively normal with precipitation of 1540,1255 , and $1562 \mathrm{~mm}$, respectively. The large variability in precipitation among those years yielded substantial differences in streamflow and water table depth in this area. These wide ranges of climatic and hydrological conditions were optimal for model testing to determine whether any model components were biased and whether the model could perform equally well under different conditions outside the calibration time period (Kirchner, 2006). 
Several quantitative methods were used to evaluate model performance, including the model efficiency $(E)$ (Nash and Sutcliffe, 1970), the root mean squared error (RMSE), and the coefficient of determination $\left(R^{2}\right)$. The parameter sensitivity was evaluated by minimizing RMSE and maximizing E of both streamflow and water table depth as objective functions. The model performance was evaluated by calculating $E$ for daily and monthly streamflow and water table depth (Moriasi et al., 2007).

MIKE SHE was initialized first with a group of baseline input parameters, most of which were empirical values (Table 2). For calibration, the model was rerun with alternative values for each of the input parameters until the maximum $E$ and minimum RMSE for streamflow and water table depth were achieved. The range of alternative values for each input parameter was chosen to allow for adequate variability, with the minimum values for most of parameters set at about $10-25 \%$ of their empirical values and the maximum values at about $200 \%$ of their empirical values (Table 3). However, much larger ranges were needed for infiltration rate, hydraulic conductivities and the coefficient of canopy interception due to their low sensitivity in this watershed. The optimized parameter values from the calibration procedure were then used for the model validation. All simulations were carried out with one year warm up starting from 2002.

\section{Results and discussion}

\subsection{Calibration}

The calibration results indicated that surface detention storage was a critical calibration parameter with substantial influence on water table depth and streamflow (Fig. 3a and b). For example, the average water table depth increased from -0.74 to $-0.38 \mathrm{~m}$ when surface detention storage was set, respectively, to 5 and $100 \mathrm{~mm}$. Calibration for daily streamflow yielded an optimal value of surface detention storage at about $50 \mathrm{~mm}$ (given its range of 5-100 mm). However, calibration for water table depth suggested that detention storage would vary between 25 and $50 \mathrm{~mm}$ because the simulated average water table levels displayed different patterns as compared to the measured water table level $(-0.58 \mathrm{~m})$, showing higher values by 7 and $20 \mathrm{~cm}$ when detention storage was set to 50 and $100 \mathrm{~mm}$, but lower values by 16 and 4 $\mathrm{cm}$ when detention storage was set to 5 and $25 \mathrm{~mm}$. Most importantly, distributed detention storage was needed because it provided more optimized simulation output ( $E$ of 0.70 for daily streamflow and 0.90 for water table depth) than uniform detention storage ( $E$ of 0.58 for daily streamflow and 0.49 for water table depth). As a result, distributed detention storage was determined to vary $11-180 \mathrm{~mm}$, based on the topography and the observation of the surface runoff resulted from storm events in this site (Harder et al., 2007), with an average of $36 \mathrm{~mm}$. This average detention storage was com-

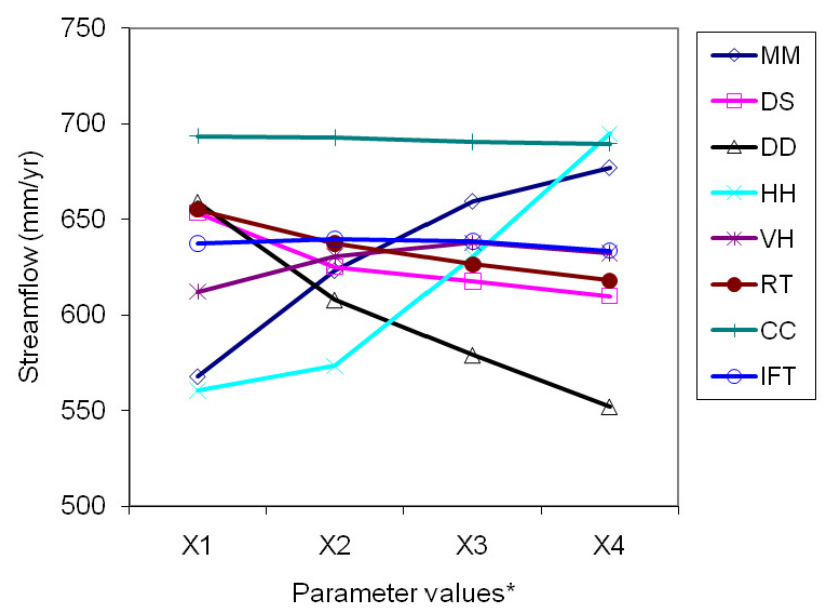

Fig. 3a. Sensitivity of streamflow to inputs *: $X 1=10, X 2=30$, $\mathrm{X} 3=50$ and $\mathrm{X} 4=70 \mathrm{~m}^{1 / 3} \mathrm{~s}^{-1}$ for Manning $M(\mathrm{MM}) ; 5,25$, 50 and $100 \mathrm{~mm}$ for detention storage (DS); 5, 25, 50 and $100 \mathrm{~cm}$ for Drainage depth (DD); $1 \times 10^{-6}, 4 \times 10^{-5}, 4 \times 10^{-4}$ and $5 \times 10^{-3} \mathrm{~ms}^{-1}$ for horizontal hydraulic conductivity $(\mathrm{HH})$; $5 \times 10^{-7}, 5 \times 10^{-6}, 5 \times 10^{-5}$ and $1 \times 10^{-4} \mathrm{~ms}^{-1}$ for vertical hydraulic conductivity $(\mathrm{VH}) ; 30,50,70$ and $90 \mathrm{~cm}$ for plant rooting depth (RT); 0.05, $0.2,0.4$ and $0.8 \mathrm{~mm}$ for coefficient of canopy interception (CC); $8 \times 10^{-6}, 8 \times 10^{-5}, 8 \times 10^{-4}$ and $1 \times 10^{-3} \mathrm{~ms}^{-1}$ for infiltration rate (IFT).

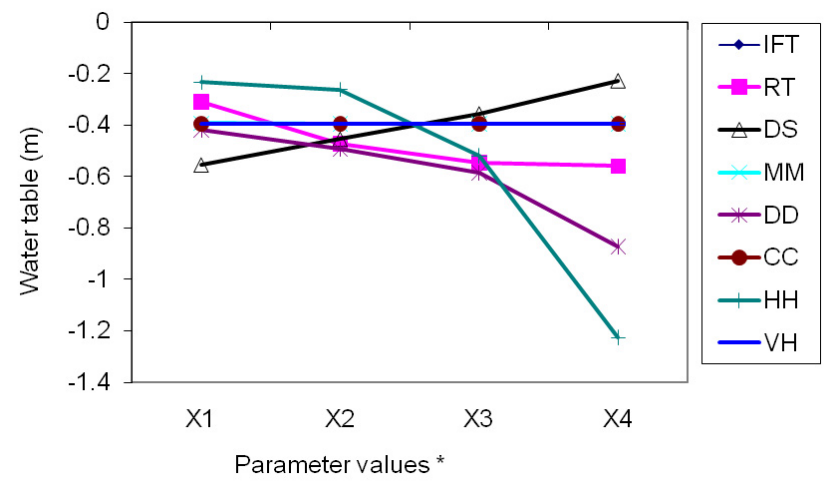

Fig. 3b. Sensitivity of water table to parameter inputs *: $X 1=10$, $\mathrm{X} 2=30, \mathrm{X} 3=50$ and $\mathrm{X} 4=70 \mathrm{~m}^{1 / 3} \mathrm{~s}^{-1}$ for Manning $M(\mathrm{MM}) ; 5$, 25,50 and $100 \mathrm{~mm}$ for detention storage (DS); 5, 25, 50 and $100 \mathrm{~cm}$ for Drainage depth (DD); $1 \times 10^{-6}, 4 \times 10^{-5}, 4 \times 10^{-4}$ and $5 \times 10^{-3} \mathrm{~ms}^{-1}$ for horizontal hydraulic conductivity $(\mathrm{HH})$; $5 \times 10^{-7}, 5 \times 10^{-6}, 5 \times 10^{-5}$ and $1 \times 10^{-4} \mathrm{~ms}^{-1}$ for vertical hydraulic conductivity $(\mathrm{VH}) ; 30,50,70$ and $90 \mathrm{~cm}$ for plant rooting depth (RT); 0.05, 0.2, 0.4 and $0.8 \mathrm{~mm}$ for coefficient of canopy interception (CC); $8 \times 10^{-6}, 8 \times 10^{-5}, 8 \times 10^{-4}$ and $1 \times 10^{-3} \mathrm{~ms}^{-1}$ for infiltration rate (IFT).

parable to the $40 \mathrm{~mm}$ value used by Harder et al. (2006) in their hydrological simulation using DRAINMOD model on the same site.

Plant rooting depth may be the second most critical calibration parameter, especially for water table depth. In 


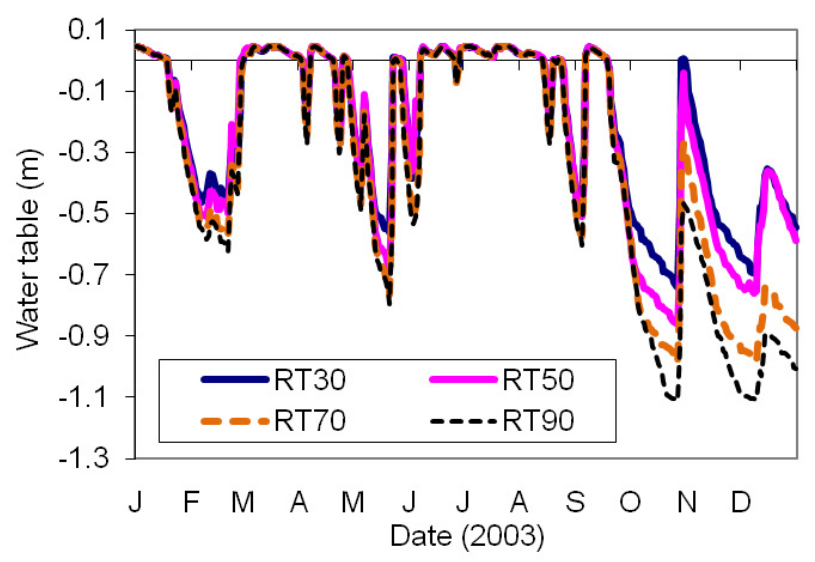

Fig. 4. Effect of plant rooting depth on water table in WS80. The four curves marked by RT30, RT50, RT70 and RT90 represent plant rooting depth of $30,50,70$ and $90 \mathrm{~cm}$, respectively.

the discussions of calibration with 2003 data hereafter, we wanted to distinguish a high precipitation period (1 January to 9 September; $1606 \mathrm{~mm}$ ) from a low precipitation period (10 September to 31 December; $164 \mathrm{~mm}$ ) because calibration parameters may respond to them differently. Plant rooting depth showed weak effects on streamflow ( $E$ of $0.42-$ 0.64 , RMSE of 0.21-0.27) during the low precipitation period, but no effects ( $E$ of 0.57 , RMSE of 3.48-3.50) in the high precipitation period (Fig. 3a, Table 3). In contrast, plant rooting depth strongly affected water table depth ( $E$ of $0.05-$ 0.54, RMSE of 0.17-0.24) (Fig. 3b, Table 3), especially during the low precipitation period (Fig. 4). The average simulated water table depth was 5.5 and $3.0 \mathrm{~cm}$ shallower than the observed data when plant rooting depth was set to 30 and $50 \mathrm{~cm}$, but 5.0 and $9.2 \mathrm{~cm}$ deeper than the observed when plant rooting depth was set to 70 and $90 \mathrm{~cm}$. Water table decreased with an increase in plant rooting depth, similar to the pattern reported by Skaggs et al. (1991) in their simulation with DRAINMOD for an Atlantic Coastal watershed in North Carolina. However, sensitivity of water table level to plant rooting depth was reduced during the high precipitation period because of the abundant supply of water in the root zone.

Drainage depth, i.e., the depth from the average ground surface to the position where the flow of drainage water can occur, was another critical calibration parameter that required representation of distributed values. Drainage depth was determined to change between $0.05-0.95 \mathrm{~m}$ (average of $0.35 \mathrm{~m}$ ) in space based on the variability in topography (slope) and the distance to streams (Table $4 \mathrm{a}$ and b). The calibration results showed that streamflow ( $E$ of $0.50-0.64$ ) was less sensitive to drainage depth than water table depth ( $E$ of -4.96-0.45) (Table 3, Fig. 5). The reason for this low sensitivity of streamflow was likely to be the dominance of the surface flow in WS80 with shallow water table and shallow stream (Harder et al., 2007).
Table 4a. Measured and simulated groundwater table in 2003$2004^{\mathrm{a}}$

\begin{tabular}{cccccccc}
\hline Well & \multirow{2}{*}{$\begin{array}{c}\text { ELE } \\
(\mathrm{m})\end{array}$} & \multicolumn{2}{c}{ Meanured } & \multicolumn{2}{c}{ Simulated } & $R^{2}$ & Significance \\
& STD & Mean & STD & & $(P)$ \\
\hline W1 & 9.2 & -0.77 & 0.29 & -0.82 & 0.37 & 0.50 & $<0.01$ \\
W2 & 8.2 & -0.42 & 0.60 & -0.52 & 0.40 & 0.59 & $<0.01$ \\
W3 & 9.1 & -0.28 & 0.29 & -0.31 & 0.39 & 0.78 & $<0.01$ \\
W4 & 8.8 & -0.70 & 0.38 & -0.71 & 0.37 & 0.55 & $<0.01$ \\
W5 & 9.6 & -0.86 & 0.47 & -0.77 & 0.35 & 0.66 & $<0.01$ \\
W6 & 8.7 & -1.29 & 0.72 & -1.45 & 0.42 & 0.66 & $<0.01$ \\
W7 & 8.1 & -1.46 & 0.55 & -1.49 & 0.40 & 0.74 & $<0.01$ \\
W8 & 5.6 & -0.77 & 0.42 & -0.74 & 0.39 & 0.78 & $<0.01$ \\
W9 & 5.5 & -0.54 & 0.38 & -0.52 & 0.38 & 0.78 & $<0.01$ \\
W10 & 8.6 & -1.36 & 0.59 & -1.28 & 0.64 & 0.88 & $<0.01$ \\
\hline
\end{tabular}

a: $R^{2}$ is coefficient of determination; STD is standard deviation; The unit of water table depth is meter and negative value means water table below ground surface; W1-W10 are the well identification number (Fig. 1).

Surface roughness (i.e., Manning $M$, which is the inverse of the commonly used Manning's n) affected streamflow ( $E$ of 0.53-0.64, RMSE of 3.21-3.65; Fig. 3a), but showed little effect on water table depth ( $E$ of $0.46-0.47$, RMSE of $0.182-0.183$; Fig. $3 b$ ). Manning $M$ was to be set at 35 based on streamflow responses and on physical conditions of WS80 (e.g., the planar topography, high litter content on the ground).

Horizontal hydraulic conductivity affected both streamflow and water table depth. The optimal values in calibration for streamflow and water table depth ranged from 0.00001 $0.00008 \mathrm{~ms}^{-1}$ (soil-area-weighted average) with $E$ of 0.77 and RMSE of 2.53 for streamflow and $E$ of 0.46 and RMSE of 0.18 for water table. Because large spatial differences in soil properties and topography may lead an obvious difference in horizontal hydraulic conductivity, distributed values were used with a spatial range of $0.00001-0.0001 \mathrm{~ms}^{-1}$ based on the topography and the spatial distribution of soil type and texture in this site.

The coefficient of canopy interception $\left(C_{\text {int }}\right)$ was insignificant in calibrating for either streamflow ( $E$ of $0.55-0.57$, RMSE of 3.48-3.57) or water table depth ( $E$ of $0.54-0.55$, RMSE of 0.168-0.171). The low sensitivity of streamflow and water table depth to $C_{\text {int }}$ may be due to the low proportion of the canopy storage in the precipitation (about 4\%). However, $C_{\text {int }}$ during the low precipitation period became significant when canopy storage fraction in the total precipitation increased to about $11 \%$. The optimal value of $C_{\text {int }}$ was determined to be $0.225 \mathrm{~mm}$ (given the optimum range of $0.05-0.35 \mathrm{~mm}$ ). This value of $C_{\mathrm{int}}$ corresponded to canopy storage capacity of $0.69 \mathrm{~mm}$, which is similar to the value of 
Table 4b. Measured and simulated water table for automatic wells in 2005-2007 ${ }^{\mathrm{a}}$.

\begin{tabular}{cccccccccccc}
\hline & \multicolumn{4}{c}{ W3 } & \multicolumn{1}{c}{ M } & \multicolumn{3}{c}{ W7 } \\
Measured & \multicolumn{2}{c}{ Simulated } & \multicolumn{3}{c}{ Measured } & \multicolumn{3}{c}{ Simulated } \\
year & Mean & STD & Mean & STD & $R^{2}$ & Mean & STD & Mean & STD & $R^{2}$ \\
\hline 2005 & -0.40 & 0.37 & -0.48 & 0.47 & 0.89 & -1.14 & 0.63 & -1.13 & 0.51 & 0.66 \\
2006 & -0.50 & 0.33 & -0.60 & 0.48 & 0.89 & -1.45 & 0.73 & -1.43 & 0.61 & 0.46 \\
2007 & -0.64 & 0.32 & -0.76 & 0.43 & 0.85 & -1.52 & 0.73 & -1.66 & 0.52 & 0.54 \\
\hline
\end{tabular}

a: $R^{2}$ is the coefficient of determination; STD is standard deviation; There were no measured water table data from $2005-2007$ for the manual wells.

Table 5. Measured and simulated daily and monthly streamflow in 2004-2008 ${ }^{\mathrm{a}}$.

\begin{tabular}{lllllll}
\hline Year & $R^{2}$ & $\mathrm{E}$ & $\mathrm{MM}$ & $\mathrm{MS}$ & $\mathrm{CV}-\mathrm{M}$ & $\mathrm{CV}-\mathrm{S}$ \\
\hline 2004 daily & 0.60 & 0.56 & 0.28 & 0.37 & 4.34 & 3.11 \\
2004 monthly & 0.84 & 0.84 & 8.6 & 11.4 & 1.54 & 0.99 \\
2005 daily & 0.61 & 0.51 & 0.84 & 0.87 & 2.50 & 2.74 \\
2005 monthly & 0.99 & 0.98 & 25.5 & 26.3 & 0.97 & 0.87 \\
2006 daily & 0.77 & 0.75 & 0.38 & 0.52 & 2.99 & 1.71 \\
2006 monthly & 0.95 & 0.84 & 11.5 & 16.1 & 1.18 & 0.88 \\
2007 daily & 0.79 & 0.73 & 0.16 & 0.21 & 3.49 & 1.75 \\
2007 monthly & 0.97 & 0.90 & 4.9 & 6.4 & 2.10 & 1.21 \\
2008 daily & 0.68 & 0.64 & 0.87 & 0.95 & 4.69 & 4.48 \\
2008 monthly & 0.94 & 0.91 & 29.5 & 33.5 & 1.42 & 1.06 \\
2004-2008 daily & 0.67 & 0.62 & 0.51 & 0.59 & 4.35 & 3.91 \\
2004-2008 monthly & 0.94 & 0.93 & 16.0 & 18.7 & 1.61 & 1.23 \\
\hline
\end{tabular}

a: Daily streamflow is mm per day; monthly streamflow is $\mathrm{mm}$ per month; $R^{2}$ is coefficient of determination; $E$ is model efficiency; $\mathrm{MM}$ is the mean of measurements; MS is the mean of the simulations; CV-M is the observed coefficient of variation; $\mathrm{CV}-\mathrm{S}$ is the simulated coefficient of variation.

$0.7 \mathrm{~mm}$ observed by Harder (2004) in the same watershed for the same period.

Vertical hydraulic conductivity and infiltration rate showed little effect on either streamflow or water table depth (Table 3). This lack of model sensitivity to these two parameters was likely related to the shallow water table level and the boundaries of the surface water flow and subsurface flow on the watershed. WS80 was bound by the roads that were well compacted to minimize lateral flow across the border. Vertical hydraulic conductivity and infiltration rate were defined by initial values in Table 2, changing with soil type and texture.

The results from sensitivity analysis suggest that model calibration using both streamflow and distributed water table depth may have great advantages over the single param-

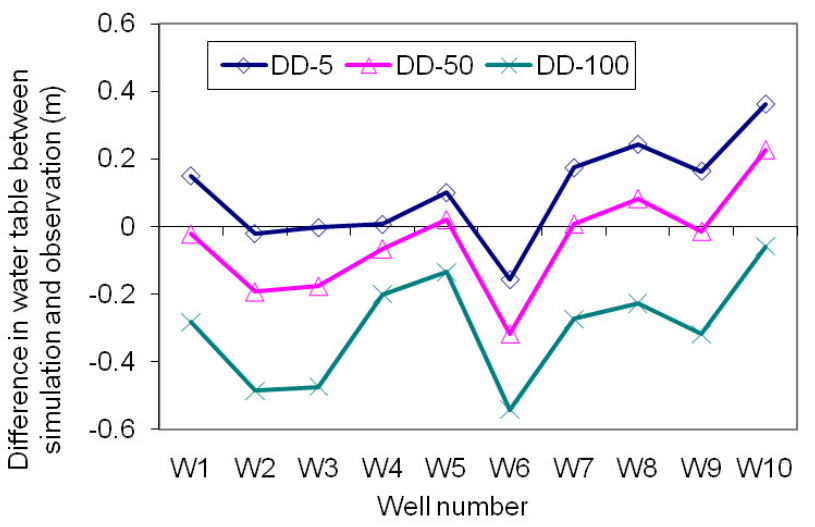

Fig. 5. Differences between observed and simulated water table depth under different drainage depth in calibration. The curves marked by DD-5, DD-50 and DD-100 represent drainage depth of 5,50 and $100 \mathrm{~cm}$.

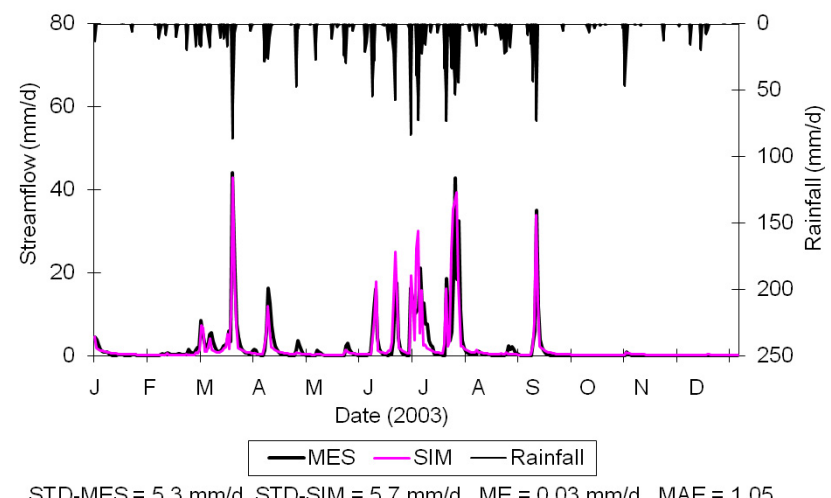

Fig. 6a. Measured and simulated daily streamflow in 2003. MES is measurement; SIM is simulation; STD is standard deviation; ME is mean error between simulation and observation; MAE is mean absolute error between simulation and observation.

eter approach in selecting optimal parameter values and constructing uncertainty bounds for model inputs as suggested by Blasone et al. (2008). However, calibration results are 


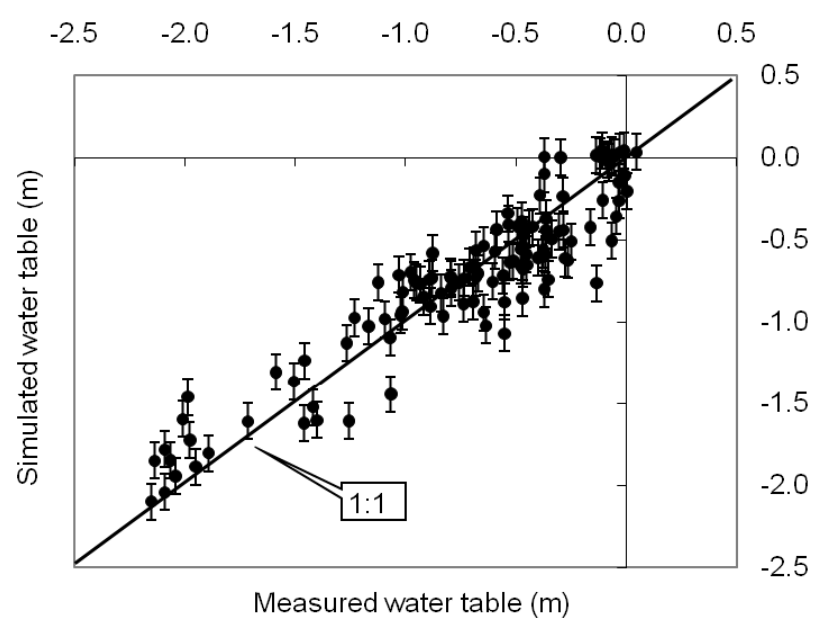

Fig. 6b. Water table at the 10 wells with synchronized observation in 2003. Bar is the mean absolute error between observation and simulation.

likely to be different catchment-to-catchment. For example, our calibration results showed that, to simulate hydrology of the study area for 2003, plant rooting depth was not important to streamflow during wet periods but became important during low precipitation periods, whereas plant rooting depth was a significant factor to water table depth with an optimal value. However, this cannot occur in those catchments where the highest water table is below the root zone, such as the study sites of Blasone et al. (2008) and Vázquez et al. (2008). Most importantly, distributed surface detention storage was needed to accommodate for the differences in optimal parameter values when calibrating for both streamflow and water table depth. Thus, bi-criteria calibration should be used at least to assure prediction accuracy and internal consistency with distributed hydrological models. In addition, our results indicate that distributed parameter values should be expected in areas of high spatial heterogeneity, especially for those parameters that influence water table dynamics and for watersheds with a shallow water table and low-relief topography.

MIKE SHE was well calibrated based on the $E$ and $R^{2}$ values for daily and monthly streamflow, and daily water table depth (i.e., $E$ of $0.53,0.96$ and $0.90 ; R^{2}$ of $0.53,0.96$ and 0.90 , respectively; Table 1), most of which were within the "very good" rating range $(E>0.75)$ suggested by Moriasi et al. (2007). However, there were a few problems. For example, streamflow was over-predicted on 20 June, 2 and 3 July of 2003 and the dry periods when the stream was dry (Fig. 6a). The over-prediction of daily streamflow on 2 and 3 July of 2003 might be related to the measurement errors caused by beaver activities (Harder et al., 2007). However, a more likely reason is that the over-prediction during the dry periods results from an artifact of MIKE SHE that does not allow a river/stream to dry out (Lu et al., 2006; see additional discussion below). Nonetheless, despite the over-prediction

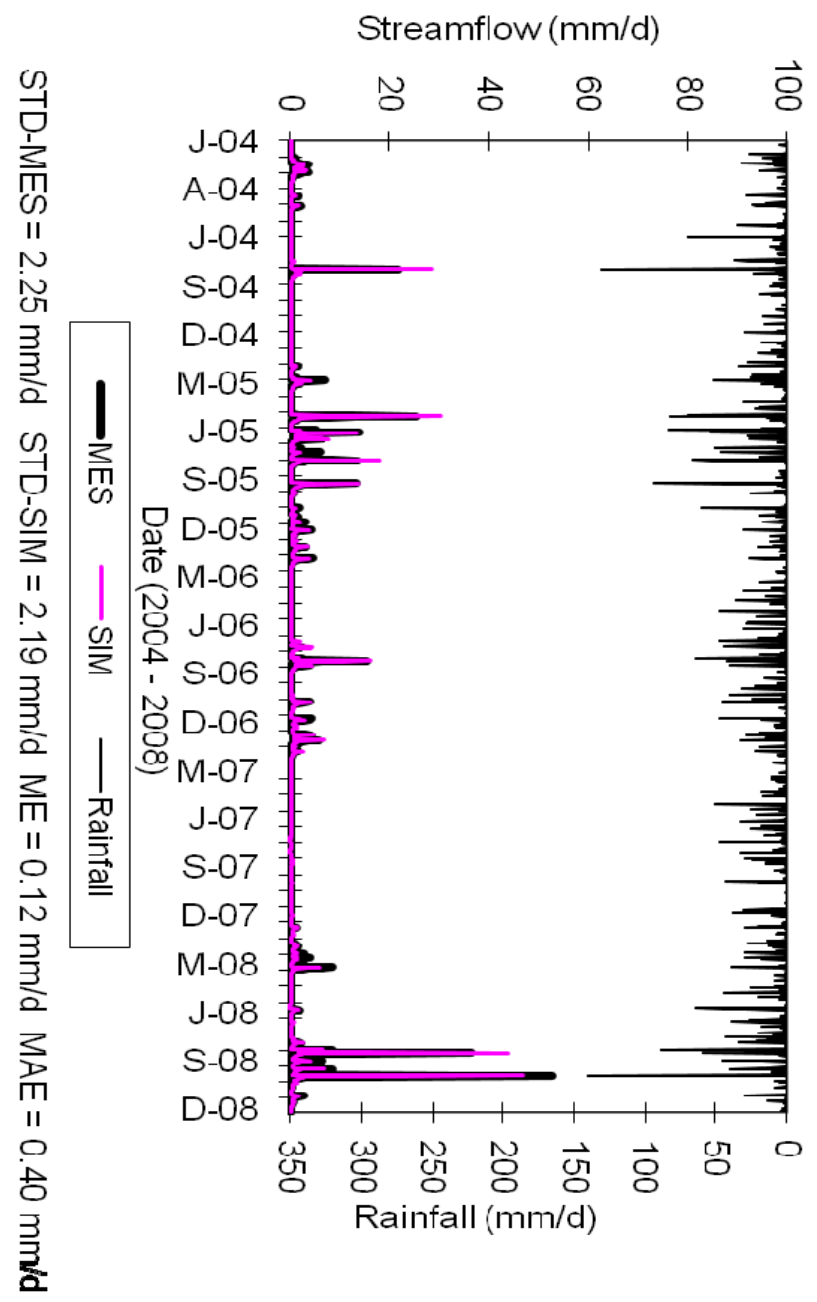

Fig. 7a. Daily streamflow in 2004-2008. MES is measurement; SIM is simulation; STD is standard deviation; ME is mean error between simulation and observation; MAE is mean absolute error between simulation and observation.

of the streamflow during the dry periods, MIKE SHE was able to capture most of the dynamics of streamflow and water table depth in the watershed (Fig. 6a and b).

\subsection{Model validation}

The model was validated using streamflow and water table depth measured between 2004 and 2008. The predicted daily and monthly streamflow were in good agreement with the measurements ( $R^{2}$ of $0.60-0.99$ for both; Table 5$)$. The model efficiency $(E)$ values $(0.84-0.98)$ for monthly streamflow were in the "very good" rating range $(E>0.75)$ prescribed by Moriasi et al. (2007). However, despite the good correlation between the observed and predicted values and the high $E$ values, the modeled streamflow tended to be higher than the observations (Table 5), especially for 2004. The higher simulated streamflow may be attributed to 


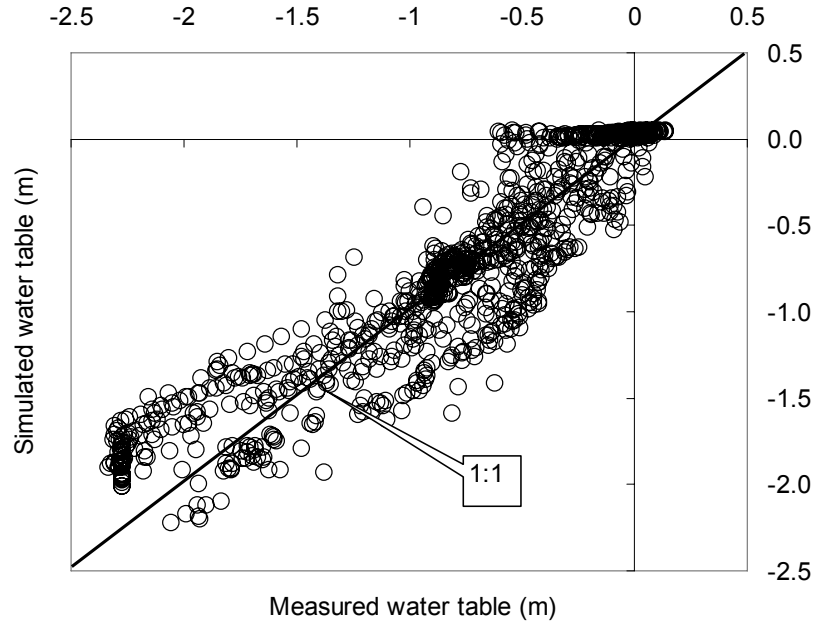

Fig. 7b. Water table depth at well W3 and W7 in 2004-2005.

over-predictions during dry periods (Fig. 7a), especially on days with heavy precipitation, such as 29 August 2004 and 2 June 2005 (Fig. 7a). The over-prediction of streamflow occurred consistently when there were high intensity precipitation events during normally dry periods. This type of response should be related to the artifact in MIKE SHE does not allow for no-flow periods ( $\mathrm{Lu}$ et al., 2006). In the case of the intermittent streams, it is typical to have no-flow periods, for example during the dry period from the fall of 2003 to the summer of 2004 and the summer of 2007; however in these cases, MIKE SHE maintained a very low stream flow. This artifact in MIKE SHE was not reported before by Lu et al. (2006), because most of the applications were in larger watersheds, but it is an important consideration for drainage areas with intermittent streamflow.

There was good $(p<0.01)$ correspondence between the predicted water table depth and the measured values from two wells in the watershed (Fig. 7b). The simulated temporal water table dynamic was also in good correspondence with the measured data (Table $4 \mathrm{a}$ and b and Fig. 7c), with the $E$ values of $0.66,0.80$ for the manual and automatic wells respectively. Lu et al. (2009) have also shown that MIKE SHE is effective at predicting water table depth in the central Florida coastal plain.

\subsection{Spatial pattern of water table levels}

Although the surface topography of this watershed is planar, there is considerable variation in water table depth (Table $4 \mathrm{a}$ and $b$ ). The simulated distribution of water table depth and flow direction reflected a complex pattern (Fig. 8a). The variation in water table depth was most pronounced during dry periods (Fig. 8b), as opposed to a relatively uniform distribution when the site was near saturation (Fig. 8a). Studying the same watershed, Harder et al. (2007) reported that storm-

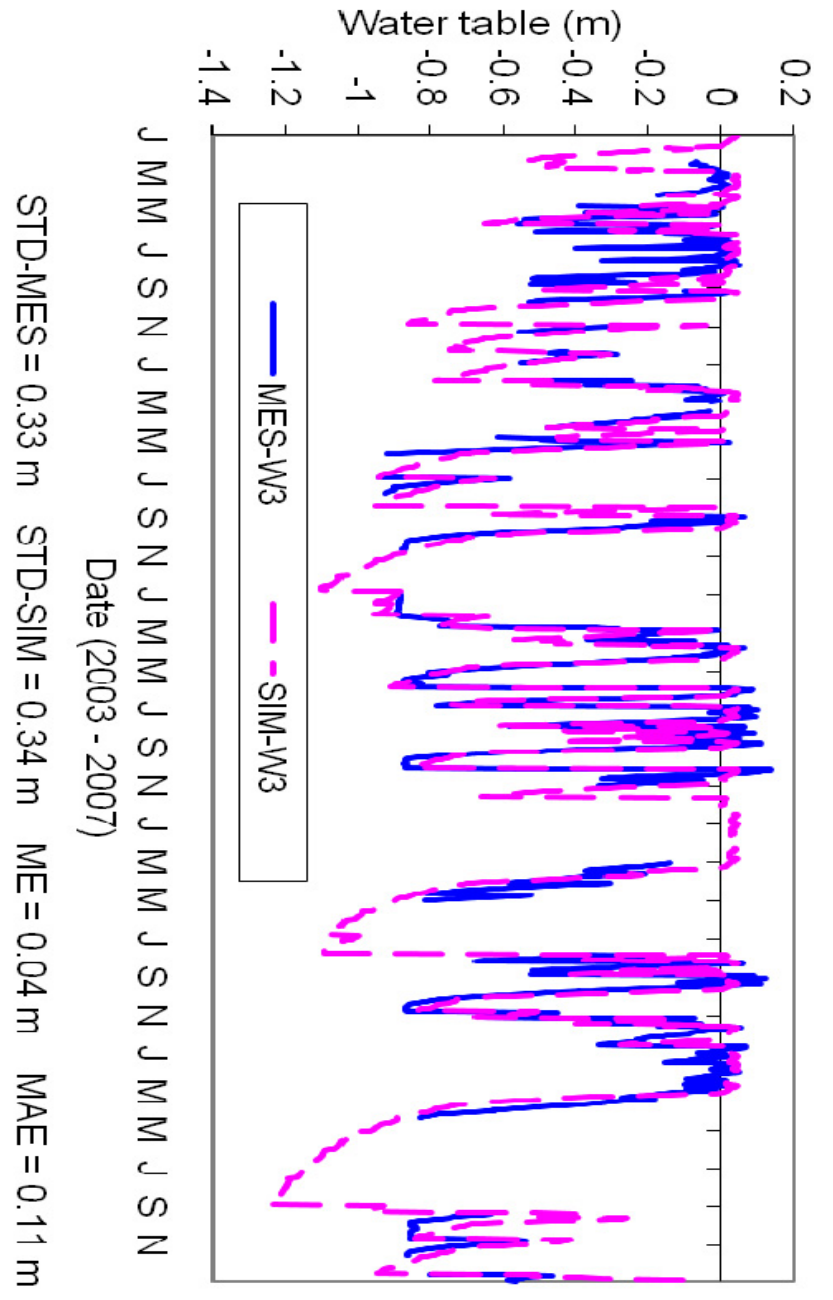

Fig. 7c. Temporal variation of groundwater table depth at well W3. This is a shallower well, and the depth was $54 \mathrm{~cm}$ below the ground surface before March of 2004, $94 \mathrm{~cm}$ after (Harder et al., 2007).

flow was generated primarily from saturated area, which was consistent with our findings on water table depth and flow direction during raining periods. The water table in dry seasons was substantially lower than wet seasons (Fig. 8b), over $40 \mathrm{~cm}$ below the surface in a large area of the study site in very dry periods. The difference in water table depth between dry and wet periods was 1-2 $\mathrm{m}$ depending on the location within the watershed. The magnitude of water table rise during wet periods and fall during dry periods was related to topography, with the very flat area having less variation as compared to areas with some relief. 


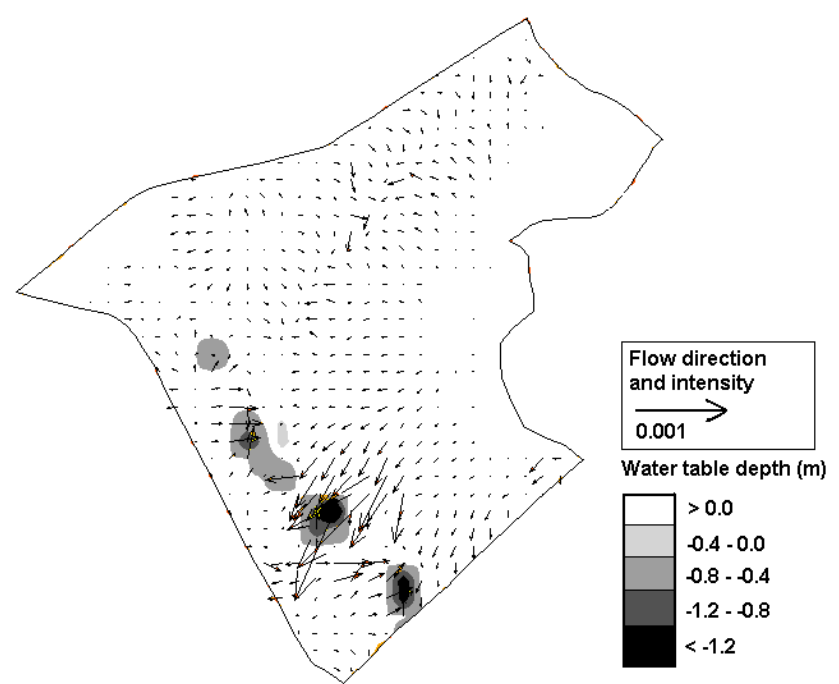

Fig. 8a. Spatial distribution of water table depth and flow direction after an intense storm.

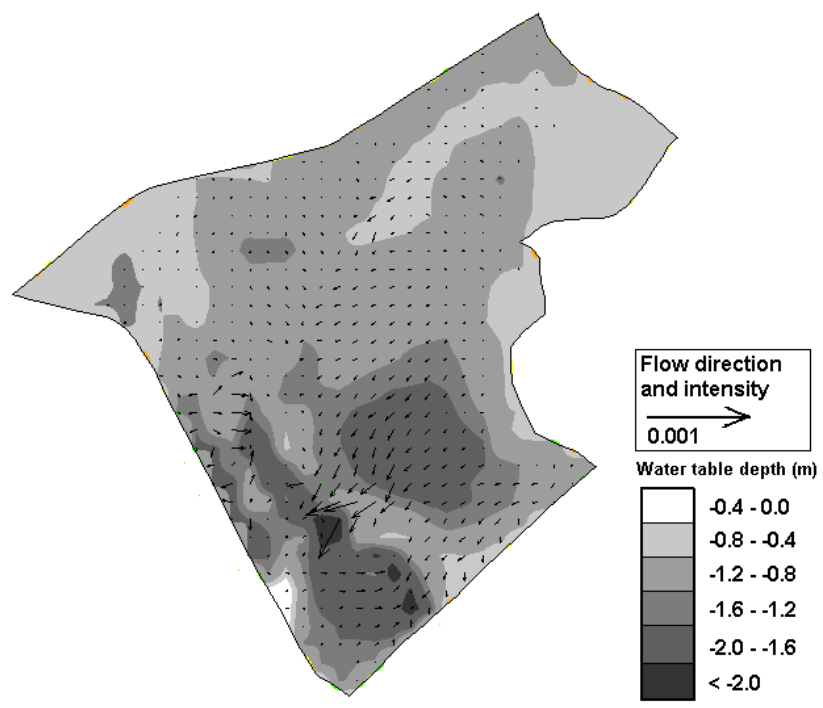

Fig. 8b. Spatial distribution of water table depth and flow direction in the duration of low precipitation.

\section{Conclusions}

The MIKE SHE simulations showed that streamflow from this lower coastal plain forested watershed was highly sensitive to surface detention storage, drainage depth, surface roughness and horizontal hydraulic conductivity. Water table dynamics were highly sensitive to plant rooting depth and the coefficient of canopy interception, which likely reflects the influence of vegetation through evapotranspiration. Having measurements of ET and/or canopy interception measurements would improve the model calibration. Modeling the spatial distribution of shallow groundwater table at watershed scales remains challenging. This exercise represents one of the few attempts to evaluate the MIKE SHE model using the bi-criteria approach (e.g., streamflow and water table depth). The results showed that calibration using the bi-criteria was better than a single-criterion approach to obtain optimum model input parameters, especially for those parameters that are sensitive to specific conditions. For example, plant rooting depth was influential on water table depth but did not directly affect streamflow in this first-order watershed. Model calibration using multi-criteria approaches should be advantageous for assuring prediction accuracy when applying distributed models to simulate hydrology for this type of forested watersheds. Qualitative and quantitative results from the calibration and validation procedures showed that MIKE SHE was capable of predicting the dynamic water table and streamflow for both daily and monthly time steps. However, the systematic over-prediction of streamflow during periods of no-flow is an issue that must be considered when applying MIKE SHE to first order watersheds with intermittent flow.

Edited by: J. Liu

\section{References}

Abbott, M., Bathurst, J., Cunge, J., O’Connell, P., and Rasmussen, J.: An Introduction to the European Hydrological System - Systeme Hydrologique Europeen, "SHE", 1: History and Philosophy of a Physically-based, Distributed Modelling System, J. Hydrol., 87, 45-59, 1986a.

Abbott, M., Bathurst, J., Cunge, J., O'Connell, P., and Rasmussen, J.: An Introduction to the European Hydrological System Systeme Hydrologique Europeen, "SHE", 2: Structure of a Physically-based, Distributed Modelling System, J. Hydrol., 87, 61-77, 1986b.

Amatya, D. and Skaggs, R.: Hydrologic modeling of a drained pine plantation on poorly drained soils, Forest Science, 47, 103-114, 2001.

Amatya, D., Sun, G., Trettin, C., and Skaggs, R.: Long-term forest hydrologic monitoring in coastal Carolinas, in: First Interagency Conference on Research in the Watersheds, edited by: Renard, K. G., McElroy, S. A., Gburek, W. J., Canfield, H. E., and Scott, R. L., 27-30 October 2003, US Department of Agriculture, Agricultural Research Service, 279-285, 2003.

Arnold, J., Allen, P., and Morgan, D.: Hydrologic model for design and constructed wetlands, Wetlands, 21, 167-178, 2001.

Beven, K.: A manifesto for the equifinality thesis, J. Hydrol., 320, 18-36, 2006.

Blasone, R. S., Madsen, H., and Rosbjerg, D.: Uncertainty assessment of integrated distributed hydrological models using GLUE with Markov chain Monte Carlo sampling, J. Hydrol., 353, 1832, 2008.

Boyle, D., Gupta, H., and Sorooshian, S.: Multicriteria calibration of hydrologic models, in: Calibration of Watershed Models, edited by: Duan, Q., Gupta, H., Sorooshian, S., Rousseau, A., Turcotte, R., AGU, 185-196, 2003. 
Cui, J., Li, C., and Trettin, C.: Analyzing the ecosystem carbon and hydrologic characteristics of forested wetland using a biogeochemical process model, Global Change Biology, 11, 278289, 2005 .

DHI: MIKE SHE Technical Reference, Version 2005, DHI Water and Environment, Danish Hydraulic Institute, Denmark, 2005.

El-Nasr, A., Feyen, J., and Berlamont, J.: Modeling a Mid-size Catchment Using a Physically Distributed Hydrologic Model, Amer. Inst. of Hydrology, Hydrol. Sci. \& Techn., Special Issue, 17, 1-10, 2001.

El-Sadek, A.: Upscaling field scale hydrology and water quality modeling to catchment scale, Water Resour. Manage., 21, 149169, 2007.

Federal Register: Changes in hydric soils of the United Sates, 13 July 1994.

Federal Register: Hydric soils of the United States, 18 September 2002.

Freer, J., Beven, K., and Peters, N.: Multivariate Seasonal Period Model Rejection Within the Generalised Likelihood Uncertainty Estimation Procedure, in: Calibration of Watershed Models, edited by: Duan, Q., Gupta, H., Sorooshian, S., Rousseau, A., Turcotte, R., AGU, 69-88, 2003.

Graham, D. and Butts, M.: Chapter 10 flexible integrated watershed modeling with MIKE SHE, in: Watershed Models, edited by: Singh, V. and Frevert, D., CRC Press, 2005.

Harder, S.: Hydrology and Water Budget of a First Order Forested Coastal Plain Watershed, South Carolina, M.Sc. Thesis, College of Charleston, Charleston, South Carolina, 168 pp., 2004.

Harder, S., Amatya, D., Callahan, T., and Trettin, C.: Modeling the Monthly Water Balance of a First Order Coastal Forested Watershed, Hydrology and Management of Forested Wetlands Proceedings of the International Conference 8-12 April 2006, New Bern, North Carolina, Publication Date 8 April 2006, 701P0406, 218-230, 2006.

Harder, S., Amatya, D., Callahan, T., Trettin, C., and Hakkila, J.: Hydrology and water budget for a forested Atlantic Coastal Plain watershed, South Carolina, JAWRA, 43, 563-575, 2007.

Heath, R.: Hydrology of the Albemarle-Pamlico Region of North Carolina, USGS Water Resources Investigation 9-75, 98 pp., 1975.

Hook, D., Buford, M., and Williams, T.: Impact of Hurricane Hugo on the South Carolina Coastal Plain Forest, J. Coastal Research (Special Issue No. 8), 291-300, 1991.

Kirchner, J.: Getting the right answers for the right reasons: Linking measurements, analysis, and models to advance the science of hydrology, Water Resour. Res., 42, W03S04, doi:10.1029/2005WR004362, 2006.

Lamb, R., Beven, K., and Myrabø, S.: Use of spatially distributed water table observations to constrain uncertainty in a rainfall-runoff model, Adv. Water Resour., 22, 305-317, doi:10.1016/S0309-1708(98)00020-7, 1998.

Liu, J., Williams, J., Zehnder, A., and Yang, H.: GEPICmodeling wheat yield and crop water productivity with high resolution on a global scale, Agri. Syst., 94, 478-493, doi:10.1016/j.agsy.2006.11.019, 2007.

Lu, J., Sun, G., Amatya, D., Harder, S., and McNulty, S.: Understanding the hydrological response of a coastal plain watershed to forest management and climate change in South Carolina, USA Hydrology and Management of Forested Wetlands Proceedings of the International Conference 8-12 April 2006, New Bern, North Carolina, Publication Date 8 April 2006, 701P0406, 231239, 2006.

Lu, J., Sun, G., McNulty, S., and Comerford, N.: Sensitivity of pine flatwoods hydrology to climate change and forest management in Florida, USA, Wetlands 29, 826-836, 2009.

Mansell, R., Bloom, S., and Sun, G.: A model for wetland hydrology: Description and Validation, Soil Science, 165, 384-397, 2000.

Martinez, C., Campbell, K., Annable, M., and Kiker, G.: An object-oriented hydrologic model for humid, shallow water-table environments, J. Hydrol., 351, 368-381, doi:10.1016/j.jhydrol.2008.01.002, 2008.

Meixner, T., Gupta, H., Bastidas, L., and Bales, R.: Estimating parameters and structure of a hydrologic model using multiple criteria, in Calibration of Watershed Models, edited by: Duan, Q., Gupta, H., Sorooshian, S., Rousseau, A., Turcotte, R., AGU, 213-228, 2003.

Mernild, S., Hasholt, B., and Liston, G.: Climatic control on river streamflow simulations, Zackenberg River drainage basin, northeast Greenland, Hydrol. Process., 22, 1932-1948, doi:10.1002/hyp.6777, 2008.

Monteith, J.: Evaporation and Environment, in: Proceedings of the 19th Symposium of the Society for Experimental Biology, edited by: Fogg, G., Cambridge University Press, New York, New York, 205-234, 1965.

Moriasi, D., Arnold, J., Liew, M. W. V., Bingner, R., Harmel, R., and Veith, T.: Model Evaluation Guidelines for Systematic Quantification of Accuracy in Watershed Simulations, ASABE 50(3), 885-899, 2007.

Nash, J. and Sutcliffe, J.: River flow forecasting through conceptual models - Part I: A discussion of principles, J. Hydrol., 10, 282 290, 1970.

Refsgaard, J.: Parameterization, calibration and validation of distributed hydrologic models, J. Hydrol., 198, 69-97, 1997.

Riekerk, H., Jones, S., Morris, L., and Pratt, D.: Hydrology and water quality of three small lower coastal plain forested watersheds, in: Proceedings of the Soil and Crop Science Society of Florida, edited by: Horner, E., Soil and Crop Science Society of Florida, Gainesville, FL, 38, 105-111, 1979.

Sahoo, G., Ray, C., and Carlo, E.: Calibration and validation of a physically distributed hydrological model, MIKE SHE, to predict streamflow at high frequency in a flashy mountainous Hawaii stream, J. Hydrol., 327, 94-109, doi:10.1016/j.jhydrol.2005.11.012, 2006.

SCS (Soil Conservation Service): Soil Survey of Berkeley County, South Carolina, United States Department of Agriculture, 99 pp. 1980.

Shrestha, R. and Rode, M.: Multi-objective calibration and fuzzy preference selection of a distributed hydrological model, Environ, Modeling and Software, 23, 1384-1395, doi:10.1016/j.envsoft.2008.04.001, 2008.

Singh, R., Subramanian, K., and Refsgaard, J.: Hydrological modeling of a small watershed using MIKE SHE for irrigation planning, Agr. Water Manage., 41, 149-166, 1999.

Skaggs, R., Gilliam, J., and Evans, R.: A Computer Simulation Study of Pocosin Hydrology, Wetlands, 11(special issue), 399416, 1991.

Staes, J., Rubarenzya, M., Meire, P., and Willems, P.: Modelling 
hydrological effects of wetland restoration: a differentiated view, Water Sci. Technol. 59, 433-441, 2009.

Sun, G., Riekerk, H., and Comerford, N.: Modeling the hydrologic impacts of forest harvesting on Florida flatwoods, JAWRA, 34, 843-854, 1998.

Sun, G., Lu, J., Gartner, D., Miwa, M., and Trettin, C.: Water Budgets of Two Forested Watersheds in South Carolina, in: Proceedings of the Spring Special Conference, edited by: Higgins, R., American Water Resources Association, Miami, Florida, 199202, 2000.

Vázquez, R.F., Willems, P., and Feyen, J.: Improving the predictions of a MIKE SHE catchment-scale application by using a multi-criteria approach, Hydrol. Process., 22, 2159-2179, doi:10.1002/hyp.6815, 2008.
Vrugt, J., Braak, C. J. F. T., Clark, M., and Hyman, J.: Treatment of input uncertainty in hydrologic modeling: Doing hydrology backward with Markov chain Monte Carlo simulation, Water Resour. Res., 44, W00B09, doi:10.1029/2007WR006720, 2008.

$\mathrm{Xu}, \mathrm{C} .-\mathrm{Y}$. and Singh, V.: Evaluation of three complementary relationship evapotranspiration models by water balance approach to estimate actual regional evapotranspiration in different climatic regions, J. Hydrol., 308, 105-121, 2005.

Yan, J. and Smith, K.: Simulation of integrated surface water and ground water systems - Model formulation, Water Resour. Bull., 30, 1-12, 1994.

Zhang, Z., Wang, S., Sun, G., McNulty, S., Zhang, H., Li, J., Zhang, M., Klaghofer, E., and Strauss, P.: Evaluation of the MIKE SHE model for application in the Loess Plateau, China, JAWRA, 44, 1108-1120, 2008. 